\title{
APLIKASI PERPUSTAKAAN BERBASIS WEB DENGAN MENGIMPLEMENTASIKAN METODE SEQUENTIAL SEARCH
}

\author{
Nurwanto \\ Universitas Muhammadiyah Ponorogo \\ Jl. Budi Utomo No.10, Ronowijayan, Kec. Siman, Kabupaten Ponorogo, Jawa Timur 63471 \\ e-mail:nurwanto@umpo.ac.id
}

\begin{abstract}
ABSTRAK
Seiring perkembangan teknologi informasi, peran perpustakaan belum tergantikan secara sepenuhnya walaupun pengunjung perpustakaan semakin berkurang karena masyarakat lebih memilih membaca Electronic Book (E-Book) yang bisa didapatkan dengan mudah melalui internet. Tujuan dari penelitian ini yaitu untuk meningkatkan pelayanan masyarakat dengan membuat aplikasi perpustakaan berbasis web dengan bahasa pemrograman PHP yang dapat digunakan untuk membantu pencarian buku dengan mengimplementasikan metode Sequential Search. Implementasi metode Sequential Search pada aplikasi perpustakaan digunakan untuk mencari data buku berdasarkan kode buku, ISBN, judul buku, penulis dan penerbit yang merupakan data array/larik (1 dimensi). Selain itu, pencarian dengan metode Sequential Search pada seтиa modul pada aplikasi perpustakaan mempermudah administrator dalam mengelola sетиа data. Hasil pencarian dengan menggunakan metode Sequential Search akurat yang dapat menampilkan data buku sesuai kata kunci yang dimasukan. Aplikasi akan mencari sesuai urutan indeks array yang telah ditentukan yaitu kode buku, ISBN, judul buku, penulis dan penerbit. Hasil pengujian menggunakan metode Blackbox Testing, aplikasi pepustakaan layak untuk diimplementasikan karena dari 9 skenerio yang diujikan semuanya sukses dan sesuai hasil yang diharapkan.
\end{abstract}

Kata kunci : Perpustakaan, PHP, Sequential Search, Web.

\begin{abstract}
Along with the development of information technology, conventional libraries cannot be completely replaced even though their visitors are decreasing from time to time because people prefer to read Electronic Books (E-Books) which can be obtained easily via the internet. The purpose of this research is to improve community services by creating a web-based library application using the PHP programming language which can be used to assist book searches by implementing the Sequential Search method. The implementation of the Sequential Search method in the library application is used to search for book data based on the book code, ISBN, book title, author and publisher which is an array of data ( 1 dimension). Also, the administrators can easily manage all required data by searching using the Sequential Search method on all modules in the library application. Search results using Sequential Search method can accurately display the data book according to the keywords entered. The application will search according to a predetermined array index sequence, namely book code, ISBN, book title, author and publisher. The test results using the Blackbox Testing method indicate the library application is feasible to be implemented because of the 9 tested scenarios, all of them are successful and meet the expected outcomes.
\end{abstract}

Keywords: Library, PHP, Sequential Search, Web

\section{PENDAhuluan}

Perpustakaan merupakan suatu tempat yang berisi kumpulan buku-buku koleksi yang disusun dan diatur sedemikian rupa agar mempermudah pembaca melakukan pencarian koleksi buku. (Sutarno, 2006). Seiring perkembangan teknologi informasi, peran perpustakaan belum tergantikan secara sepenuhnya walaupun pengunjung perpustakaan semakin berkurang. Hal ini disebabkan karena 
I N F O R M A I I A

Jurnal Informatika, Manajemen dan Komputer, Vol. 13 No. 1 , Mei 2021

eISSN : 2580-3042

pISSN : 1979-0694

masyarakat lebih memilih membaca Electronic Book (E-Book) yang bisa didapatkan dengan mudah melalui internet dan dapat dibaca melalui smartphone. Selain itu, tidak jarang koleksi buku yang ada pada perpustakaan, tidak bisa memenuhi kebutuhan pembaca yang pada akhirnya membuat kecewa pembaca yang sudah datang ke perpustakaan tersebut.

Tujuan dari penelitian ini salah satunya yaitu untuk meningkatkan pelayanan kepada masyarakat dengan membuat sebuah aplikasi yang dapat digunakan untuk membantu pencarian koleksi buku yang ada di perpustakaan. Untuk mencapai tujuan tersebut, penulis mengimplementasikan metode Sequential Search pada fitur pencarian buku di aplikasi perpustakaan. Metode Sequential Search digunakan untuk mencari data dalam bentuk array/larik (1 dimensi) yang terurut maupun tidak terurut. (Triana et al., 2019). Mudah diimplementasikan pada semua bahasa pemrograman adalah salah satu kelebihan dari metode Sequential Search, selain itu karena algortima yang digunakan sangat sederhana maka proses pencarian membutuhkan waktu yang relatif sedikit atau lebih cepat. (Yuliawan, 2021) (Utami \& Apridiansyah, 2019). Dengan dirancangnya aplikasi perpustakaan dengan mengimplementasikan metode Sequential Search dapat membantu pengunjung untuk mencari dan melihat koleksi buku tanpa harus ke perpustakaan karena aplikasi dirancang berbasis web dengan menggunakan bahasa pemrograman Hypertext Preprocessor (PHP).

\section{METODOLOGI PENELITIAN}

Model Waterfall atau Linear Sequential Model merupakan model perancangan perangkat lunak dengan pendekatan secara sistematis atau berurutan. Setiap tahap dilakukan setelah tahap sebelumnya diselesaikan.

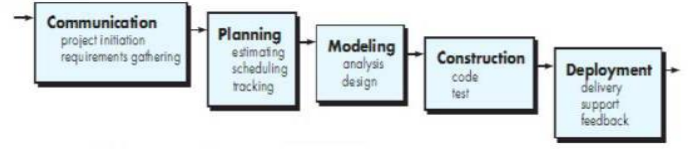

Gambar 1. Model Waterfall (R.S.Pressman, 2015).

\section{Communication}

Tujuan dari komunikasi yaitu inisiasi proyek yang dibuat seperti menganalisa masalahmasalah yang ada serta mengumpulkan data dari pihak terkait seperti kebutuhan fungsional maupun kebutuhan non fungsional. Selain itu beberapa data dapat diperoleh dari sumber lain

seperti jurnal, buku dan internet sebagai data pendukung.

2. Planning

Pada tahap ini penulis melakukan perencanaan proyek mulai dari estimasi waktu pengerjaan, sumber daya yang dibutuhkan serta pembagian tugas-tugas pada perancangan aplikasi. Selain itu, setiap tugas yang dikerjakan harus di-tracking agar semua berjalan sesuai yang dijadwalkan.

3. Modeling

Modeling dilakukan untuk menggambarkan rancangan aplikasi seperti alur sistem (Flowchart), alur data (Data Flow Diagram), relasi tabel dan desain User Interface (UI).

\section{Construction}

Tahap selanjutnya yaitu membuat aplikasi dengan bahasa pemrograman Hypertext Preprocessor (PHP) berdasarkan model yang telah ditentukan pada tahap 3. Sebelum dirilis dan didistribusikan kepada customer, dilakukan pengujian pada aplikasi untuk menemukan bug dan selanjutnya diperbaiki.

\section{Deployment}

Setelah tahap 1-4 diselesaikan maka aplikasi siap untuk didistribusikan dan diimplementasikan. Aplikasi yang sudah diimplementasikan harus dilakukan pemeliharaan secara berkala, perbaikan jika terdapat bug serta pengembangan aplikasi.

\section{HASIL DAN PEMBAHASAN}

Aplikasi perpustakaan yang dirancang mengimplementasikan metode Sequential Search disetiap fitur pencariannya. Untuk merealisasikan hal tersebut, penulis terlebih dahulu menggambarkan alur sistem (Flowchart), alur data (Data Flow Diagram), relasi tabel dan desain User Interface (UI).

\section{a. Metode Sequential Search}

Metode Sequential Search merupakan salah satu metode pencarian data berupa array/larik (1 dimensi) yang terurut maupun tidak terurut, yang dilakukan secara beruntun dan berurutan dimulai dari data pertama hingga data yang dicari tersebut ditemukan. Cara kerja metode ini dengan cara mencocokkan data yang dicari dengan semua data yang disimpan pada database (Lestari \& Latifah, 2019) (Triana et al., 2019) (Tini, 2018). Karena pencarian dilakukan secara berurutan maka waktu yang dibutuhkan untuk proses pencarian data berdasarakan letak 
I N F O R M A T I K A

Jurnal Informatika, Manajemen dan Komputer, Vol. 13 No. 1 , Mei 2021

eISSN : 2580-3042

pISSN : 1979-0694

data tersebut, jika data yang dicari terletak didepan maka waktu pencarian yang dibutuhkan lebih cepat (Yuliawan, 2021). Mudah diimplementasikan pada semua bahasa pemrograman adalah salah satu kelebihan dari metode Sequential Search, selain itu karena algortima yang digunakan sangat sederhana maka proses pencarian membutuhkan waktu yang relatif sedikit atau lebih cepat. (Yuliawan, 2021)(Utami \& Apridiansyah, 2019)

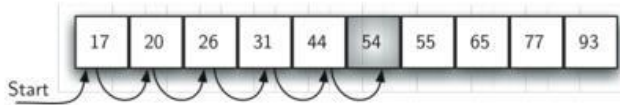

Gambar 2. Metode Sequential Search (Sonita \& Sari, 2018)

Jika pencarian data dilakukan secara online maka waktu eksekusi metode Sequential Search dapat dipengaruhi oleh koneksi internet dan posisi data yang akan di cari (Rizaldi, 2020). Berikut potongan source code implementasi metode Sequential Search pada bahasa pemrogaman PHP:

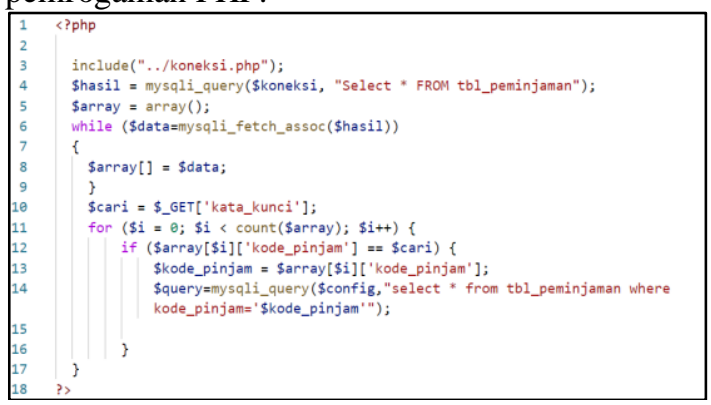

Gambar 3. Source Code metode Sequential Search pada PHP

\section{b. Desain}

1. Flowchart

Pengguna aplikasi perpustakaan terdiri dari 2 pengguna yaitu pengunjung dan administrator. Masing-masing pengguna memiliki hak akses yang berbeda.

\section{Flowchart Pengunjung}

Untuk melakukan pencarian, pengunjung bisa langsung menginputkan kata kunci seperti kode buku, ISBN, judul buku, penulis maupun penerbit.

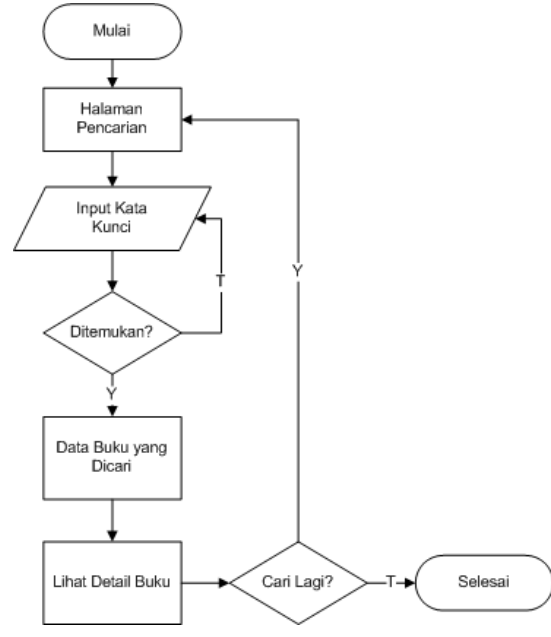

Gambar 4. Flowchart Pengunjung.

Jika data buku yang dicari ditemukan maka aplikasi akan menampilkan data buku tersebut setelah itu pengunjung dapat melihat detail buku tersebut. Flowchart pengunjung dapat dilihat pada gambar 3 .

\section{Flowchart Administrator}

Administrator memiliki hak akses penuh terhadap system yaitu administrator dapat mengakses dan mengelola semua data pada aplikasi perpustakaan.

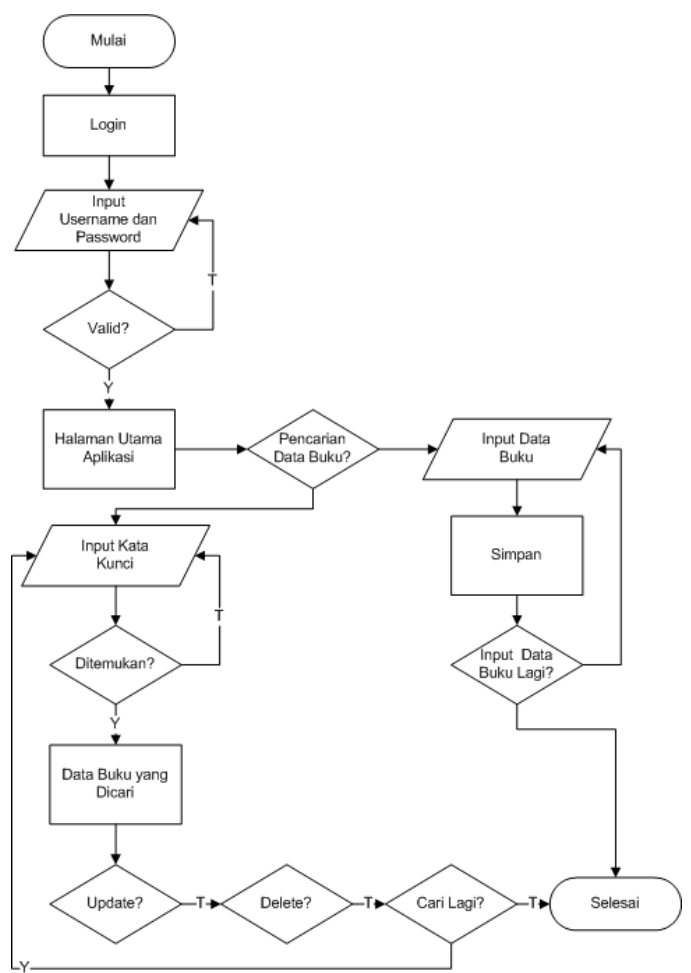

Gambar 5. Flowchart Administrator 
IN F O R M A T I A

Jurnal Informatika, Manajemen dan Komputer, Vol. 13 No. 1 , Mei 2021

eISSN : 2580-3042

pISSN : 1979-0694

Untuk mengelola data buku, administrator diharuskan verifikasi data pengguna pada halaman login dengan menginputkan username dan password, jika username dan password valid maka akan diarahkan ke halaman dashboard yang selanjutnya memilih menu data buku. Jika akan menginputkan data buku baru, administrator menginputkan semua data yang dibutuhkan dan simpan. Jika akan mengelola data buku seperti melihat, meng-update atau menghapus data buku tertentu, administrator bisa menggunakan fitur pencarian untuk menemukan buku yang akan dikelola.

\section{Data Flow Diagram}

Data Flow Diagram (DFD) digunakan untuk menggambarkan alur data pada aplikasi perpustakaan.

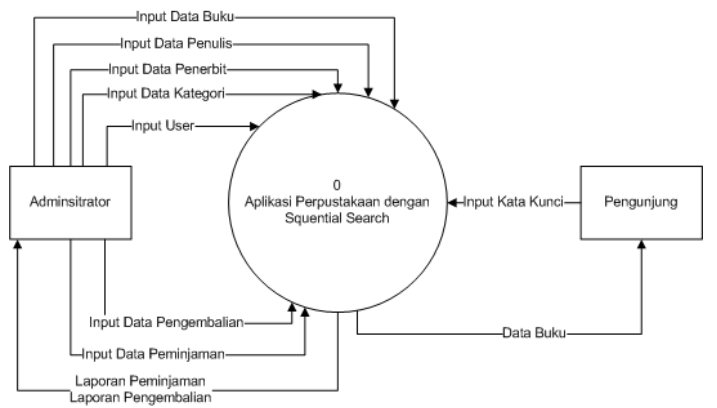

Gambar 6. Diagram Konteks

Pada gambar 5 terdapat 2 entitas luar yaitu Administrator dan Pengunjung. Administrator dapat menginputkan atau mengelola semua data pada aplikasi perpustakaan diantaranya data buku, data penulis, data penerbit, data kategori, data siswa, data peminjaman dan data pengembalian. Sedangkan pengunjung hanya bisa melihat data buku.

5. Relasi Tabel

Penyimpanan data pada aplikasi perpustakaan menggunakan DBMS MySQL yang terdiri dari beberapa tabel yang saling berelasi yaitu:

1. tbl_buku

2. tbl_penulis

3. tbl_penerbit

4. tbl_kategori

5. tbl_siswa

6. tbl_peminjaman

7. tbl_detail_peminjaman

8. tbl_pengembalian 
I N F ORM A T I R

Jurnal Informatika, Manajemen dan Komputer, Vol. 13 No. 1 , Mei 2021

eISSN : 2580-3042

pISSN : 1979-0694

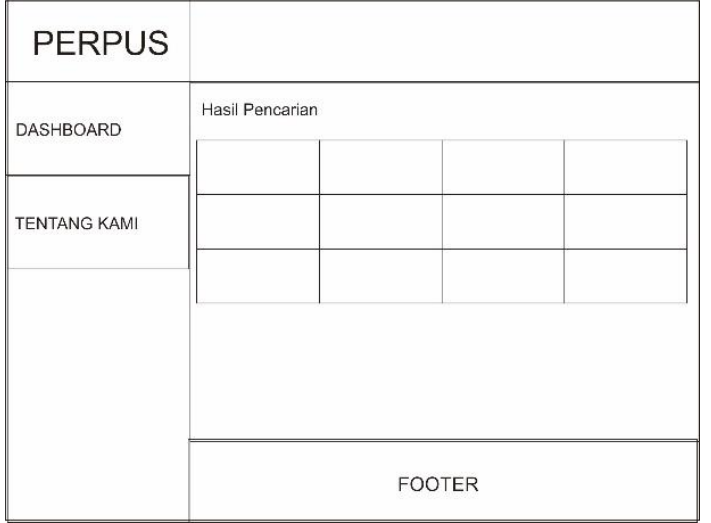

Gambar 9. Desain UI Halaman Hasil Pencarian

c. Desain UI Halaman Detail Buku

Desain halaman ini menampilkan detail buku mulai dari foto sampul, judul, penulis, penerbit, kategori serta deskripsi

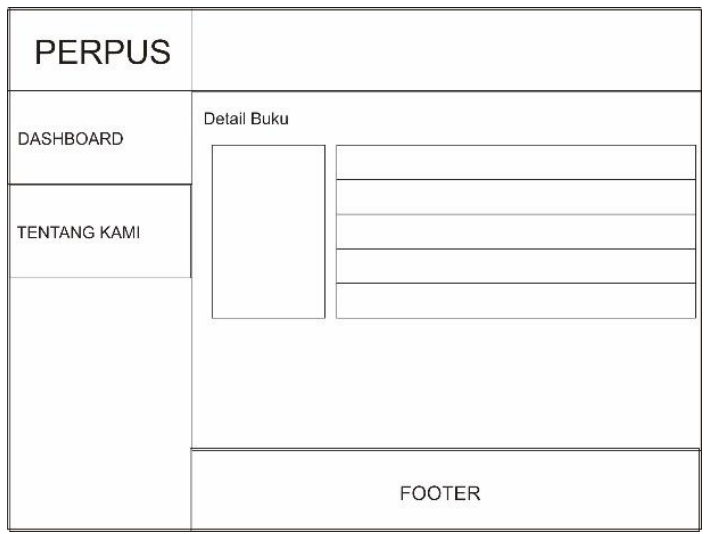

Gambar 10. Desain UI Halaman Detail Buku

\section{c. Implementasi}

Implementasi sistem yaitu tahap pembuatan aplikasi perpustakaan dengan bahasa pemrograman PHP serta DBMS MySQL yang dilakukan berdasarkan hasil perancangan.

a. Halaman Pencarian

Halaman ini dapat diakses oleh siapapun tanpa harus melakukan registrasi maupun login terlebih dahulu. Pengunjung dapat melakukan pencarian buku berdasarkan kode buku, ISBN, judul buku, penulis maupun penerbit yang diketikan pada form pencarian yang selanjutnya aplikasi akan memproses pencarian dengan metode Sequential Search.

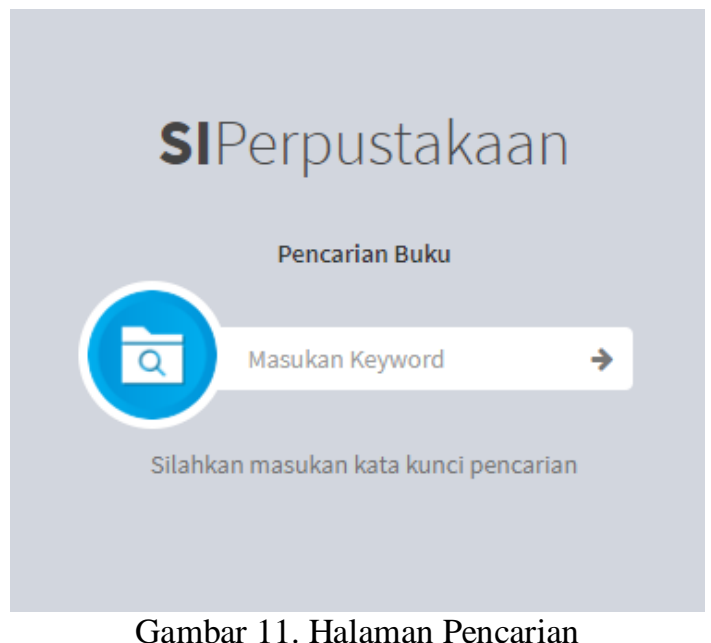

b. Halaman Hasil Pencarian

Jika data buku yang dicari ditemukan maka pengunjung akan dialihkan ke halaman hasil pencarian yang menampilkan buku berdasarkan kata kunci yang dimasukan. Data buku ditapilkan dalam bentuk tabel yang terdiri dari no, kode buku, ISBN, judul dan tahun terbit.

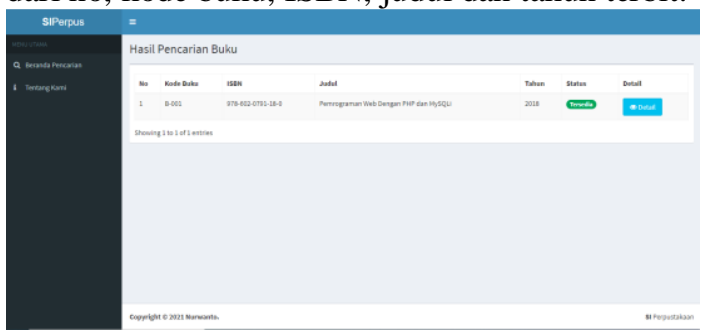

Gambar 12. Halaman Hasil Pencarian

\section{c. Halaman Detail Buku}

Data buku yang ditampilkan pada halaman hasil pencarian tidak dpat ditampilkan secara menyeluruh sehingga pengunjung dapat melihat detail buku dengan mengklik tombol "Detail".

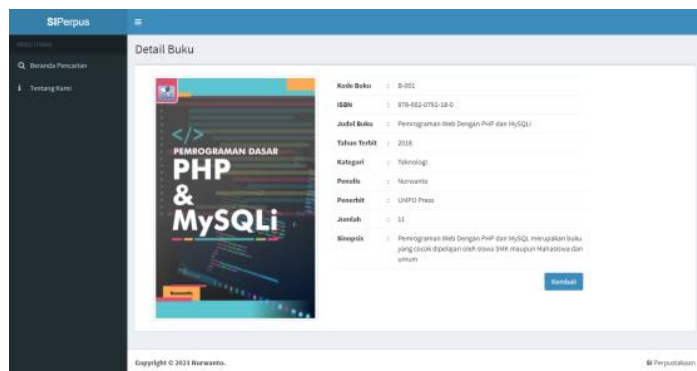

Gambar 13. Halaman Detail Buku

d. Halaman Login Administrator

Administrator memiliki hak akses penuh pada aplikasi perpustakaan sehingga dapat mengelola semua data akan tetapi sebelum dapat 
I N F ORM A T I R

Jurnal Informatika, Manajemen dan Komputer, Vol. 13 No. 1 , Mei 2021

eISSN : 2580-3042

pISSN : 1979-0694

mengelola data, administrator harus melakukan validasi data diri pada halaman login dengan menginputkan username dan password.

\begin{tabular}{l} 
Login \\
Username \\
Username \\
Password \\
\hline Password \\
\hline
\end{tabular}

Gambar 14. Halaman Login Administrator

\section{e. Halaman Dashboard Administrator}

Setelah administrator berhasil melakukan validasi data diri secara otomatis akan diarahkan ke halaman dashboard yang menampilkan beberapa informasi seperti jumlah data peminjaman, pengembalian, data buku dan data siswa. Selain itu, pada bagian header terdapat semua menu yang dapat diakses oleh administrator.

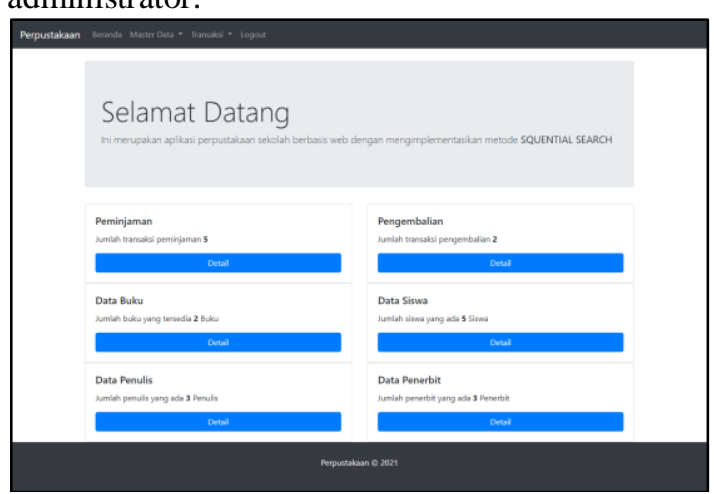

Gambar 15. Halaman Dashboard Administrator

\section{f. Halaman Data Peminjaman}

Metode Sequential Search tidak hanya diimplementasikan pada halaman pencarian buku akan tetapi diimplementasikan pada setiap form pencarian, salah satu contohnya adalah pada halaman data peminjaman buku. Pada halaman ini menampilkan semua data peminjaman dengan status pinjam, kembali dan terlambat. Untuk mencari data peminjaman hanya bisa menggunakan kata kunci kode pinjam.

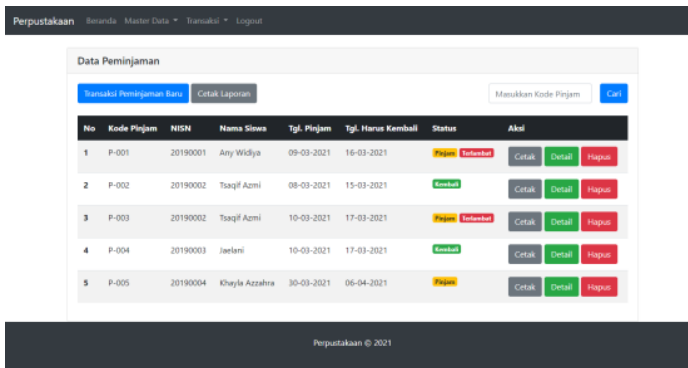

Gambar 16. Halaman Data Peminjaman

\section{d. Pengujian Sistem}

Setelah aplikasi perpustakaan selesai dikerjakan, langkah selanjutnya adalah mengujinya. Pengujian dilakukan dengan metode Blackbox Testing yaitu dengan menguji coba semua fitur yang ada pada aplikasi perpustakaan.

Tabel 1. Hasil Pengujian Sistem

\begin{tabular}{|c|c|c|c|}
\hline Fitur & $\begin{array}{l}\text { Skenario } \\
\text { Pengujian }\end{array}$ & $\begin{array}{l}\text { Hasil yang } \\
\text { diharapkan }\end{array}$ & Hasil \\
\hline $\begin{array}{l}\text { Pencari } \\
\text { an }\end{array}$ & 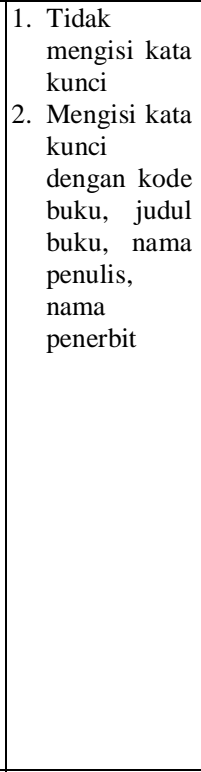 & $\begin{array}{l}\text { 1. Aplikasi } \\
\text { melakukan } \\
\text { validasi } \\
\text { dan } \\
\text { menampil } \\
\text { kan } \\
\text { peringatan } \\
\text { "Harap isi } \\
\text { bidang } \\
\text { ini" } \\
\text { 2. Aplikasi } \\
\text { melakukan } \\
\text { pencarian } \\
\text { dengan } \\
\text { metode } \\
\text { Sequential } \\
\text { Search } \\
\text { berdasarka } \\
\text { n kata } \\
\text { kunci dan } \\
\text { menampil } \\
\text { kan buku } \\
\text { dari hasil } \\
\text { pencarian }\end{array}$ & $\begin{array}{l}\text { 1. Aplikasi } \\
\text { berhasil } \\
\text { menampilk } \\
\text { an } \\
\text { peringatan } \\
\text { 2. Aplikasi } \\
\text { berhasil } \\
\text { menampilk } \\
\text { an hasil } \\
\text { pencarian } \\
\text { berdasarka } \\
\text { n kata } \\
\text { kunci }\end{array}$ \\
\hline Login & $\begin{array}{l}\text { 1. Tidak } \\
\text { mengisi } \\
\text { username dan } \\
\text { password } \\
\text { 2. Tidak } \\
\text { mengisi } \\
\text { password } \\
\text { 3. Mengisi } \\
\text { username dan } \\
\text { password } \\
\text { yang salah } \\
\text { 4. Mengisi } \\
\text { username dan } \\
\text { password } \\
\text { yang benar }\end{array}$ & $\begin{array}{l}\text { 1. Aplikasi } \\
\text { melakukan } \\
\text { validasi } \\
\text { dan } \\
\text { menampilk } \\
\text { an } \\
\text { peringatan } \\
\text { "Harap isi } \\
\text { bidang ini" } \\
\text { pada field } \\
\text { username } \\
\text { 2. Aplikasi } \\
\text { melakukan } \\
\text { validasi } \\
\text { dan } \\
\text { menampilk } \\
\text { an } \\
\text { peringatan } \\
\text { "Harap isi }\end{array}$ & $\begin{array}{l}\text { 1. Aplikasi } \\
\text { berhasil } \\
\text { menampilk } \\
\text { an } \\
\text { peringatan } \\
\text { pada field } \\
\text { username } \\
\text { 2. Aplikasi } \\
\text { berhasil } \\
\text { menampilk } \\
\text { an } \\
\text { peringatan } \\
\text { pada field } \\
\text { password } \\
\text { 3. Aplikasi } \\
\text { berhasil } \\
\text { menampilk } \\
\text { an pesan } \\
\text { pop-up }\end{array}$ \\
\hline
\end{tabular}


I N F ORM A T I R

Jurnal Informatika, Manajemen dan Komputer, Vol. 13 No. 1 , Mei 2021

eISSN : 2580-3042

pISSN : 1979-0694

\begin{tabular}{|c|c|c|c|}
\hline & & $\begin{array}{l}\text { bidang ini" } \\
\text { pada field } \\
\text { password } \\
\text { 3. Aplikasi } \\
\text { melakukan } \\
\text { validasi } \\
\text { dan } \\
\text { menampilk } \\
\text { an pesan } \\
\text { pop-up } \\
\text { "Username } \\
\text { dan } \\
\text { password } \\
\text { tidak } \\
\text { valid" } \\
\text { 4. Aplikasi } \\
\text { akan } \\
\text { mengarahk } \\
\text { an ke } \\
\text { halaman } \\
\text { dashboard } \\
\text { administrat } \\
\text { or }\end{array}$ & $\begin{array}{l}\text { 4. Aplikasi } \\
\text { berhasil } \\
\text { mengarahk } \\
\text { an ke } \\
\text { halaman } \\
\text { dashboard } \\
\text { administrat } \\
\text { or }\end{array}$ \\
\hline $\begin{array}{l}\text { Input } \\
\text { Data } \\
\text { Buku }\end{array}$ & 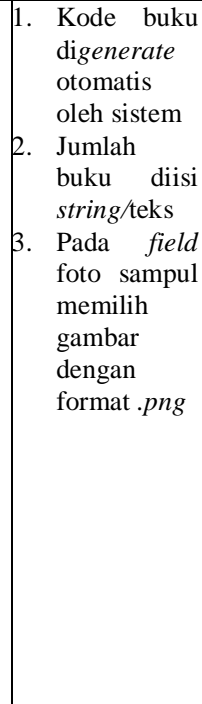 & $\begin{array}{l}\text { 1. Kode buku } \\
\text { digenerate } \\
\text { otomatis } \\
\text { oleh sistem } \\
\text { 2. Aplikasi } \\
\text { menolak } \\
\text { inputan } \\
\text { selain } \\
\text { angka/inte } \\
\text { ger } \\
\text { 3. Aplikasi } \\
\text { menerima } \\
\text { gambar } \\
\text { dengan } \\
\text { format } \\
. j p g, . j p e g, \\
. p n g \text { dan } \\
. b p m\end{array}$ & $\begin{array}{l}\text { 1. Aplikasi } \\
\text { berhasil } \\
\text { membuat } \\
\text { kode buku } \\
\text { 2. Aplikasi } \\
\text { menampilk } \\
\text { an } \\
\text { petunjuk } \\
\text { isian } \\
\text { 3. Selain } \\
\text { format } \\
\text {.jpg, .jpeg, } \\
\text {.png dan } \\
\text {.bpm, } \\
\text { aplikasi } \\
\text { akan } \\
\text { menolak } \\
\text { dan } \\
\text { menampilk } \\
\text { an } \\
\text { petunjuk } \\
\text { isian } \\
\end{array}$ \\
\hline
\end{tabular}

\section{KESIMPULAN}

Dari hasil penelitian yang telah dilakukan penulis dapat menarik kesimpulan sebagai berikut:

1. Dengan menggunakan aplikasi perpustakaan ini pengunjung dapat melakukan pencarian terlebih dahulu buku yang akan dipinjam, jika buku tersedia maka pengunjung dapat langsung ke perpustakaan untuk melakukan transaksi peminjaman. Pencarian buku dapat dilakukan dimanapun dan kapanpun selama tersedia koneksi internet. Selain itu, fitur pencarian yang mengimplementasikan metode Sequential Search pada semua modul seperti data buku, data penulis, data penerbit, data kategori, data siswa dan data peminjaman mempermudah administrator dalam mengelola data-data tersebut. Hasil pencarian dengan menggunakan metode Sequential Search dapat menampilkan data buku sesuai kata kunci yang dimasukan. Aplikasi akan mencari berdasarkan kata kunci sesuai urutan indeks array yang telah ditentukan yaitu kode buku, ISBN, judul buku, penulis dan penerbit, sehingga pengunjung tidak perlu memilih kategori pencarian yang berdasarkan kode buku, ISBN, judul buku, penulis maupun penerbit. Jika pengunjung memasukkan kata kunci penulis maka pencarian yang dilakukan mulai dari indeks ke-0 yaitu kode buku dan berhenti di indeks ke-3 yaitu penulis jika data buku yang dicari ditemukan.

2. Dari hasil pengujian yang dilakukan menggunakan metode Blackbox Testing, aplikasi pepustakaan layak untuk diimplementasikan dan digunakan karena dari 9 skenerio yang diujikan semuanya sukses dan sesuai hasil yang diharapkan.

\section{REFERENSI}

Lestari, C. T., \& Latifah, F. (2019). Aplikasi Pencatatan Keuangan Pribadi dengan Analisa SWOT Menggunakan Algoritma Sequential Search Berbasis Mobile. JISAMAR (Journal of Information System, Applied, Management, Accounting and Researh), 3(2), 11-18. http://journal.stmikjayakarta.ac.id/index.ph p/jisamar/article/view/85

R.S.Pressman. (2015). Rekayasa Perangkat Lunak: Pendekatan Praktisi Buku. In Yogyakarta: Andi. Andi.

Rizaldi. (2020). Komparasi Algoritma Sequential Searching dan Interpolation Searching Pada Studi Kasus Pencarian Data Tilang Pengadilan Negeri Samarinda. JURTI, 4(1), 86-92.

Sonita, A., \& Sari, M. (2018). Implementasi Algoritma Sequential Searching Untuk Pencarian Nomor Surat Pada Sistem Arsip Elektronik. Pseudocode, 5(1), 1-9. https://doi.org/10.33369/pseudocode.5.1.19

Sutarno, N. (2006). Perpustakaan dan Masyarakat. In Perpustakaan dan Masyarakat. Yayasan Obor Indonesia.

Tini, S. (2018). Implementation of Sequential Search Method on Android-based 
I N F O R M A T I H

Jurnal Informatika, Manajemen dan Komputer, Vol. 13 No. 1 , Mei 2021

elSSN : 2580-3042

pISSN : 1979-0694

Jakabaring Dictionary. Jurnal

Transformatika, $\quad$ 16(1), 74.

https://doi.org/10.26623/transformatika.v16

i1.830

Triana, Y. S., Rochana, A., \& Saputri, A. E. (2019). Implementasi Sequential Search

Pada Pencarian Data Tarif Aplikasi

Perjalanan Dinas Karyawan PT Telkom Akses. JURNAL RESTI (Rekayasa Sistem Dan Teknologi Informasi), 1(10), 2-8.

Utami, M., \& Apridiansyah, Y. (2019). Implementasi Algoritma Sequential Searching Pada Sistem Pelayanan Puskesmas Menggunakan Bootstrap (Studi Kasus Puskesmas Kampung Bali Bengkulu). JSAI (Journal Scientific and Applied Informatics), 2(1), 81-86. https://doi.org/10.36085/jsai.v2i1.166

Yuliawan, K. (2021). Algoritma Sequential Search Dalam Kamus Bahasa Inawatan Berbasis Android. Jurnal MediaTIK, 4(1), 35-37. 